\title{
Early school-leavers
}

Citation for published version (APA):

Huijgen, T. G., Meng, C. M., \& Verhagen, A. M. C. (2012). Early school-leavers. ROA. ROA Fact Sheets No. 002E https://doi.org/10.26481/umarof.2012002E

Document status and date:

Published: 01/01/2012

DOI:

10.26481/umarof.2012002E

Document Version:

Publisher's PDF, also known as Version of record

\section{Please check the document version of this publication:}

- A submitted manuscript is the version of the article upon submission and before peer-review. There can be important differences between the submitted version and the official published version of record.

People interested in the research are advised to contact the author for the final version of the publication, or visit the DOI to the publisher's website.

- The final author version and the galley proof are versions of the publication after peer review.

- The final published version features the final layout of the paper including the volume, issue and page numbers.

Link to publication

\footnotetext{
General rights rights.

- You may freely distribute the URL identifying the publication in the public portal. please follow below link for the End User Agreement:

www.umlib.nl/taverne-license

Take down policy

If you believe that this document breaches copyright please contact us at:

repository@maastrichtuniversity.nl

providing details and we will investigate your claim.
}

Copyright and moral rights for the publications made accessible in the public portal are retained by the authors and/or other copyright owners and it is a condition of accessing publications that users recognise and abide by the legal requirements associated with these

- Users may download and print one copy of any publication from the public portal for the purpose of private study or research.

- You may not further distribute the material or use it for any profit-making activity or commercial gain

If the publication is distributed under the terms of Article $25 \mathrm{fa}$ of the Dutch Copyright Act, indicated by the "Taverne" license above, 
U. Maastricht University in Learning!

Research Centre for Education and the Labour Market | ROA

\section{Early School-Leavers}

\section{ROA Fact Sheet}

\section{ROA-F-2012/2E}

Researchcentrum voor Onderwijs en Arbeidsmarkt | ROA Research Centre For Education and the Labour Market / ROA 


\section{Introduction}

What reasons do early school-leavers give for their prematurely leaving school? What were the early signals? Were they bullied more often than their fellow pupils who did obtain a diploma? What is the current occupation of these early school-leavers; have they returned to school, are they working, or neither? And, looking back, do they regret their decision to leave school prematurely?

To answer these questions, a survey was held among 2,I45 early school-leavers without a diploma in the Autumn of 20II. These so-called dropouts were pupils who left secondary school (Preparatory Vocational Secondary Education (PVSE), Senior General Secondary Education (SGSE), or Pre-University Education (PUE)) or Secondary Vocational Education (SVE) in the 2009/2010 school year without having obtained a basic qualification ${ }^{12}$.

The present survey among unqualified school-leavers is part of the annual school-leaver surveys carried out by the Research Centre for Education and the Labour Market (ROA). ROA has carried out these school-leaver surveys since the early 90 . For a number of sections of the questionnaires, the items for unqualified and qualified respondents are the same, allowing a comparison between the two groups for a number of key indicators. "Qualified" in this case refers to school-leavers who left school with a diploma, regardless whether this constituted a basic qualification or not.

\section{Respondents' background characteristics}

To give an idea of the composition of the data, some background characteristics of the respondents are listed below. For a more detailed overview of the background characteristics by education level, refer to Table BI in the annexes.

The group of dropouts described in this fact sheet, does not correspond to the total group of dropouts defined at the national level. As the focus is on the reasons for prematurely leaving school, those who did obtain a diploma not qualifying for the labour market (level I SGSE), have not been included in the sample. In fact, these individuals have not terminated their course and hence cannot be asked about their reasons for terminating the course. The background characteristics described here, may therefore differ from the background characteristics of the total population of dropouts in the Netherlands.

\section{Education level}

Of all respondents, one in ten did a course at SGSE or PUE level in the $2009 / 2010$ school year, approximately two in ten did a course at PVSE level, while the others did a course at SVE level.

\section{Age and gender}

The average age of the dropouts in this survey is in years and just over half of the respondents is female. Among respondents at SVE Levels 3/4, the percentage of women is fairly high $(60 \%)$, whereas it is somewhat lower (40\%) among PVSE respondents.

\section{Ethnicity}

Three out of every four dropout respondents are indigenous. Nevertheless, this percentage is slightly lower than among qualified respondents: $83 \%$ of all qualified respondents is indigenous. At PVSE level and SVE Levels $\mathrm{I} / 2$, there is also a relatively large group of dropout respondents who are non-Western immigrants (I8\% and 20\%, respectively).

\section{Family situation and children}

Almost half of all dropout respondents is from a two-parent family, against $8 \mathrm{I} \%$ of the qualified respondents. Of the dropouts at SVE Levels 3/4 in this survey, 2I\% live on their own. This is a fairly high percentage, compared with the total number of dropout respondents (I4\% of whom live on their own). SVE dropouts were the relatively most likely ones to indicate that they had a child (I4\% of all dropouts at SVE Levels $\mathrm{I} / 2$ and $7 \%$ of the dropouts at SVE Levels $3 / 4$ ). In particular women fail to complete their education because of children: $89 \%$ of the respondents with a child is female.

The dropouts from SGSE/PUE in this survey were the most likely ones to come from a two-parent family, to not have any children, and to (almost) always speak Dutch with their parents. Their parents are also most likely to be higher educated (HVE/(UE $\left.{ }^{3}\right)$. Dropouts who prematurely terminated a course at SVE Levels I/2 were the least likely ones to come from a two-parent family and to (almost) always speak Dutch at home. They also most often indicated that they had a child and that their parents had a low-level education (Lower Secondary General Education (LGSE)/ Initial Professional Education (IPE) ${ }^{4}$, or PVSE).

\section{Main reasons for dropping out}

The dropouts were given a list of I9 possible reasons, in which they could indicate to what extent each of the reasons played a role in their decision to stop their course prematurely. They were then asked which of these reasons was the main one for dropping out. Figure I provides a clustered overview of these main reasons for dropping out, sorted by education level. For a full list of main reasons, see Table $\mathrm{B}_{2}$ in the annexes. 
Figure 1

Main reasons for dropping out, by education level

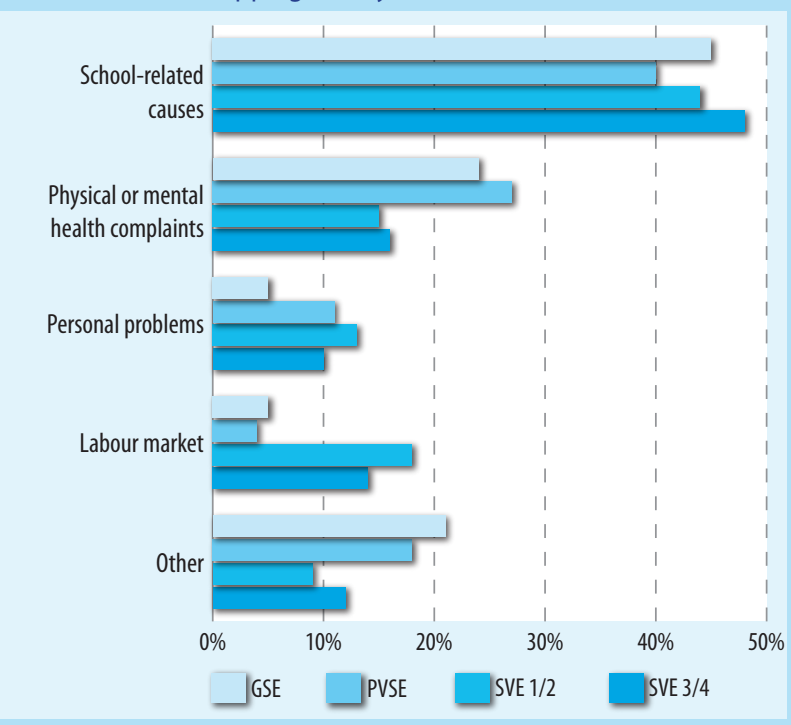

In all, school-related causes are reported most often as the main reason for dropping out (45\%). The second place is for physical and mental health complaints ( $18 \%)$. This means that the most common reasons for dropping out are similar to those in previous years.

Figure I shows that dropouts at all education levels indicate that a school-related cause was the main reason for their dropping out. The most frequently mentioned reasons that come under this heading are "the content of the course was not what I wanted (after all)", "the course was badly organised", and "the course was too difficult and/or I failed the final examination". Dropouts from SVE Levels 3/4 most often mention school-related causes, compared to dropouts from other education levels (48\%). Both among male and among female dropouts, school-related causes are the most common main reason. The same goes for indigenous and immigrant dropouts. This indicates that gender or ethnicity play no role in referring to school-related causes as the main reason for dropping out.

Physical and mental health complaints are mentioned more often by SGSE/PUE (24\%) and PVSE (27\%) dropouts than by SVE (Levels I/2: I5\%, and Levels 3/4: I6\%) dropouts as main reason for leaving school prematurely. Half of this main category consists of dropouts who mentioned "mental problems" as the main reason. "Illness" is another common reason listed in this category. Of all dropouts who refer to physical or mental health complaints as the main reason, the majority is female $(6 \mathrm{I} \%)$. The percentage of immigrant and indigenous dropouts is comparable to the percentage in the sample, which means that ethnicity appears to play no role in mentioning physical or mental health complaints as the main reason.

The labour market is mentioned relatively more often as a reason for leaving school prematurely by SVE dropouts (Levels I/2: I8\%, and Levels 3/4: I4\%) than by SGSE/ PUE dropouts (5\%) and PVSE dropouts (4\%). This is not entirely surprising, because SVE students come into contact with the labour market through their traineeship/ work placement and hence are probably more exposed to this 'pull factor'. Also among boys and immigrants (both Western and non-Western), the labour market is mentioned slightly more often as the main reason for dropping out.

Figure 2 shows whether there is a relationship between the reasons mentioned as having played a (very) important role in the decision to drop out of a course ('(very) important role') and the reasons mentioned as having been crucial for the decision ('main reason'). The points in the diagram represent the I9 reasons for dropping out. The further a point is (horizontally) removed from the diagonal dotted line, the more dropouts mentioned this reason as having played a (very) important role, but not as the decisive reason. The fact that the points, as one moves further to the right on the $\mathrm{X}$ axis, are increasingly further removed from the dotted line, indicates that many dropouts listed multiple reasons as (very) important for their decision.

Figure 2

Important role versus main reason for dropping out

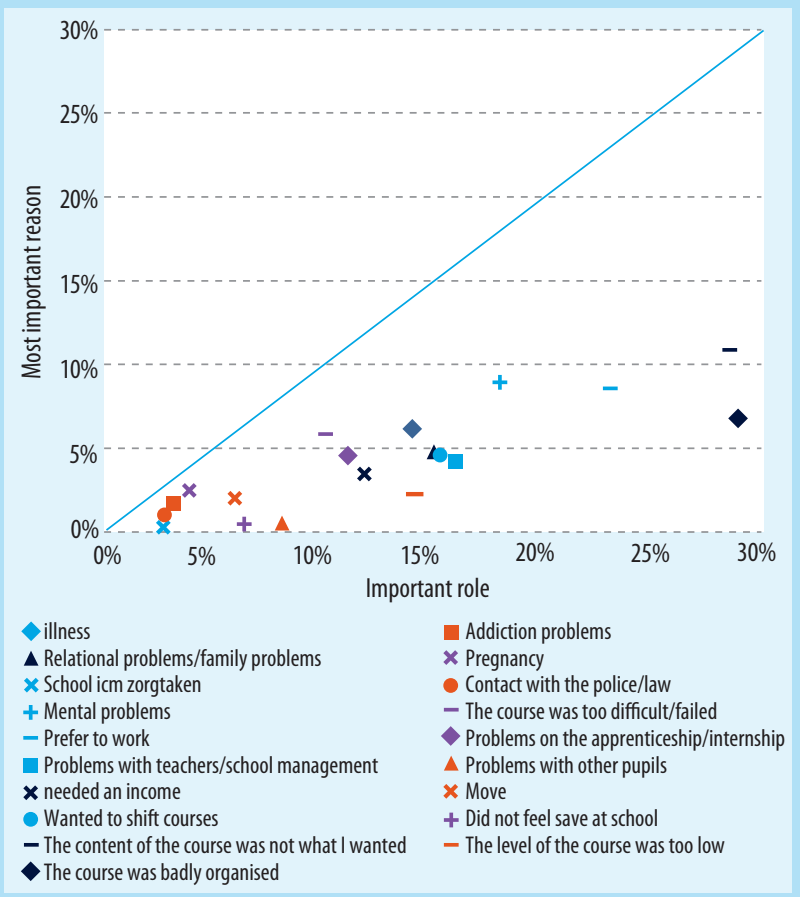

At the bottom left in the figure, there is a cluster of points. These are reasons that were mentioned relatively little by dropouts as having played a (very) important role in their decision to leave school prematurely, but where those who did mention this as having played a (very) important role, usually also referred to it as the main reason. For example, there are relatively few dropouts for whom addiction issues played a (very) important role ( $\square$ ), but for those who faced addiction issues, it was often also the main reason for dropping out.

On the right-hand side of the diagram, there are several points that are quite far from the diagonal dotted line. The reasons 'the course was badly organised' $(\bullet)$ is the 
furthest removed from the dotted line. This means that there are relatively many dropouts for whom the inadequate organisation of the course played a (very) important role in their decision to leave school prematurely, but that there are relatively few dropouts for whom this was the crucial factor (main reason) for their decision. The same goes for dropouts who chose the wrong course ('(content of) the course was not what I wanted'), who preferred to take a job, or who had mental problems. There are relatively many dropouts for whom mental problems played a (very) important role in their decision, but for a large majority of these dropouts the mental problems were not the decisive factor.

\subsection{Early signals for dropping out}

The dropouts were asked whether they had ever skipped school and if so, how often and why. The results show that $60 \%$ of all dropouts skipped school at some stage, of whom one third $(34 \%)$ did so once or twice a week, or (almost) every day. This is an increase of the percentage of truants against the previous survey (2010). In the latter survey, $52 \%$ said that they had skipped school at some stage. Within the group of truants, the frequency of skipping school is comparable to the previous survey. Of the SVE dropouts, more than half (Levels I/2: 59\%, and Levels 3/4: 70\%) reported having skipped school. Of all secondary education dropouts, slightly less than half (48\% of SGSE/PUE and $44 \%$ of the PVSE dropouts) had skipped school at some stage. The increase of the percentage of truants, however, need not mean that there is an increase of truancy. Because of all the (policy and other) measures, the number of dropouts has decreased in the past few years, increasingly leaving the 'hard core' of dropouts. Table I lists the reasons for skipping school, divided into five main categories, by education level of the truant dropouts. For the full list of the reasons for skipping school, refer to Table $\mathrm{B}_{3}$ in the annexes.

Table I shows that a school-related cause was the most common reason for skipping school (49\%). The most frequently mentioned reasons in this category were "because some lessons were not interesting" and "because the entire course was uninteresting". Dropouts at all education levels mentioned school-related causes most often as reasons for skipping school. Among the dropouts at SVE Levels 3/4, there is even a majority (58\%) who stated this as a reason for truancy.

Mental and physical health complaints were listed as truancy reasons in particular by SGSE/PUE (22\%) and PVSE (24\%) dropouts. This category consists mainly of dropouts who said that the reason for skipping school was "because I was too tired". There are also several dropouts who mentioned "mental problems" as a reason for truancy.

Relatively few dropouts skipped school because of personal problems (4\%). Within this category, a problematic home environment was the primary reason for truancy.

The lure of the labour market was an important reason for skipping school for particularly dropouts from SVE Levels I/2 (I3\%). It is not surprising that SVE pupils are most likely to skip school because of the lure of the labour market, because they are the most likely to get into contact with the labour market during their studies.

Lastly, there are quite a few dropouts who indicated that there was 'another' reason for their truancy (22\%). This shows that the reasons for skipping school are often very diverse and differ for each person.

Truancy may be an early signal for dropping out. This is likely in particular when a certain factor is both a reason for truancy and the main reason for dropping out. Table 2 shows that the reason for skipping school often corresponds with the main reason for dropping out. This can be seen in the highlighted fields, which represent the highest percentages in the rows.

A large majority of dropouts who mentioned 'schoolrelated causes' as a reason for truancy $(60 \%)$, also referred to 'school-related causes' as the main reason for dropping out. Half of the dropouts who mentioned 'personal problems' as the reason for truancy $(50 \%)$, also referred to 'personal problems' as the main reason for dropping out. This indicates that in particular among pupils who have problems at school or who have personal problems, truancy can be an early signal for dropping out. To pick up this early signal, truants should be monitored and coached more intensively. It is wise to pay extra attention to truants who mention school-related causes (lessons and/or the course are uninteresting, too difficult, or too easy; cancelled lessons; problems in class, either with fellow pupils or with teachers, bullying) or personal problems (problematic home environment; private problems; pregnancy) as reasons for skipping school.

The dropouts were asked with whom they spoke about their decision to leave school, before they definitely abandoned the course. The dropouts whose reason for skipping school corresponded with the main reason for dropping out, had slightly more often talked with 'someone' about their decision to leave school than the total group of dropouts ( $83 \%$ against $81 \%$ ). The people with whom they spoke more often, were in particular their parents ( $77 \%$ instead of $69 \%$ ) and friends (27\% instead of $20 \%)$. Surprisingly, dropouts whose reason for truancy corresponds with the main reason for leaving school prematurely, turn out to have spoken about their choice with individuals within school a little less (see the bottom four lines in Table 3). Dropouts who had never skipped school, on the other hand, had spoken more often with individuals within school about their decision to leave school. In this group of dropouts, there are at any rate more who had spoken with 'someone' $(86 \%)$. It is possible that the dropouts who had never skipped school, in principle would like to have stayed at school, which is why they skipped school less and tried harder to talk with people about their decision to leave school prematurely.

The dropouts were asked whether they were forced by school to abandon their course, because the maximum duration had been reached (having failed the final exam twice) or because they had broken school rules. Most dropouts $(83 \%)$ replied that they had not been forced by 
Table 1

Reasons for skipping school, by education level (\%)

\begin{tabular}{|c|c|c|c|c|c|}
\hline \multirow[b]{2}{*}{ Reason for skipping school } & \multicolumn{4}{|c|}{ Education level } & \multirow[b]{2}{*}{ Total } \\
\hline & GSE & PVSE & SVE $1 / 2$ & SVE $3 / 4$ & \\
\hline School-related causes & 42 & 32 & 43 & 58 & 49 \\
\hline Physical or mental health complaints & 22 & 24 & 16 & 17 & 18 \\
\hline Personal problems & 5 & 6 & 5 & 3 & 4 \\
\hline Labour market & 2 & 5 & 13 & 6 & 8 \\
\hline Other & 31 & 34 & 22 & 16 & 22 \\
\hline Total & 100 & 100 & 100 & 100 & 100 \\
\hline
\end{tabular}

Table 2

Reason for skipping school, by main reason for dropping out (\%)

\begin{tabular}{|c|c|c|c|c|c|c|}
\hline \multirow[b]{2}{*}{ Reason for skipping school } & \multicolumn{6}{|c|}{ Main reason for dropping out } \\
\hline & $\begin{array}{r}\text { School-related } \\
\text { causes }\end{array}$ & $\begin{array}{l}\text { Physical or mental } \\
\text { health complaints }\end{array}$ & $\begin{array}{l}\text { Personal } \\
\text { problems }\end{array}$ & Labour market & Other & Total \\
\hline School-related causes & 60 & 10 & 6 & 14 & 11 & $100 \%$ \\
\hline Physical or mental health complaints & 28 & 42 & 9 & 9 & 12 & $100 \%$ \\
\hline Personal problems & 10 & 18 & 50 & 6 & 17 & $100 \%$ \\
\hline Labour market & 31 & 3 & 17 & 43 & 5 & $100 \%$ \\
\hline Other & 38 & 17 & 16 & 14 & 16 & $100 \%$ \\
\hline
\end{tabular}

Table 3

With whom did you talk about your decision to leave school? (\%)

\begin{tabular}{|c|c|c|c|}
\hline Spoken with whom & All & $\begin{array}{r}\text { Reason for skipping school=reason } \\
\text { for dropping out }\end{array}$ & Never skipped school \\
\hline No one & 19 & 17 & 14 \\
\hline Someone & 81 & 83 & 86 \\
\hline Parents & 69 & 77 & 75 \\
\hline Brothers/Sisters & 11 & 10 & 11 \\
\hline Friends & 20 & 27 & 16 \\
\hline Teachers & 18 & 19 & 20 \\
\hline Mentor & 34 & 31 & 37 \\
\hline School management & 16 & 12 & 18 \\
\hline Care Advisory Team & 12 & 11 & 15 \\
\hline
\end{tabular}

\section{Table 4}

Who, according to the dropouts, has tried to keep them from leaving school? (\%)

\begin{tabular}{|c|c|c|c|c|}
\hline \multicolumn{5}{|c|}{ Who has tried to help you, and what was the objective } \\
\hline & \multirow{4}{*}{$\begin{array}{l}\text { No one } \\
\text { tried to help }\end{array}$} & \multicolumn{3}{|c|}{ Someone (school and/or other institutions) tried to help, namely: } \\
\hline & & School & Other institutions & School / Other institutions \\
\hline & & Diploma & Diploma & Other course \\
\hline & & $\%$ helped & $\%$ helped & $\%$ helped \\
\hline Total & 45 & 38 & 21 & 27 \\
\hline \multicolumn{5}{|l|}{ Education level } \\
\hline GSE & 41 & 48 & 23 & 26 \\
\hline PVSE & 28 & 46 & 34 & 49 \\
\hline SVE $1 / 2$ & 51 & 34 & 19 & 23 \\
\hline SVE $3 / 4$ & 47 & 35 & 16 & 23 \\
\hline \multicolumn{5}{|l|}{ Reason for dropping out } \\
\hline School-related causes & 49 & 33 & 15 & 25 \\
\hline Physical or mental health complaints & 32 & 49 & 29 & 34 \\
\hline Personal problems & 42 & 36 & 32 & 27 \\
\hline Labour market & 43 & 42 & 21 & 25 \\
\hline Other & 49 & 36 & 17 & 30 \\
\hline
\end{tabular}


school to stop the course. In PVSE, this percentage is slightly lower $(70 \%)$. The dropouts were also asked whether their school and/or other institutions had made any attempts to prevent their dropping out, by helping them get a diploma after all and/or by helping them switch to another course. Multiple answers could be given. Table 4 shows the results of the answers given to this question, broken down by education level and main reason for dropping out.

Table 4 shows that $45 \%$ of the dropouts indicated that there had been no one who had tried to prevent their dropping out. This means that, according to them, neither the school nor any other institution had made an attempt to help them obtain a diploma after all or to switch to another course. Of those who said that they had been helped, most indicated that they were helped by the school to obtain a diploma (38\%).

Broken down by education level, in particular SVE dropouts indicated that no one had tried to help them $(51 \%$ SVE Levels I/2, 47\% SVE Levels 3/4). PVSE dropouts were relatively least likely to indicate that no one had made any attempt to help them $(28 \%)$. This difference between the (experienced) attempts to help between SVE dropouts and PVSE dropouts could be related to the differences in the organisation and coaching between PVSE and SVE schools. In PVSE schools, pupils receive a relatively large amount of coaching, whereas in SVE schools pupils are expected to show more independence. At all education levels, more than a third to one half of the dropouts who indicated that someone had tried to help them, said that their school (among others) had tried to help them obtain a diploma after all. Of the PVSE dropouts, 49\% indicated that their school (among others) and/or other institutions had made attempts to help them switch to another course. It is likely that this high percentage is related to the fact that PVSE pupils who (are about to) drop out, are accepted in SVE without having obtained a PVSE diploma.

Broken down by main reason for dropping out, the results show that in particular dropouts who stopped because of school-related causes indicated that no one had tried to help them (49\%). The dropouts who had stopped because of physical or mental health complaints, were least likely to indicate that no one had tried to help them (32\%). Among all reasons for dropping out, most of the dropouts who indicated that someone had tried to help them, said that their school (among others) had tried to help them obtain a diploma after all.

Looking at these results, it should be noted that these need not have been actual attempts by schools or other institutions to help (or the lack thereof). It is possible that attempts were made to prevent dropouts from leaving school, but that these attempts were not experienced as such. It is also possible that the pupil concerned was not receptive to help, as a result of which the attempts were (eventually) stopped. Nevertheless, it remains remarkable that so many dropouts indicated (to have had the impression) that they were not helped by anyone.

\subsection{Bullying}

Both qualified school-leavers and dropouts were asked whether they had ever been bullied, and if so what the reason was for the bullying. Figure 3 shows - broken down by education level - relatively how many dropouts and qualified school-leavers had been bullied.

Figure 3

Having been bullied: qualified school-leavers compared to dropouts

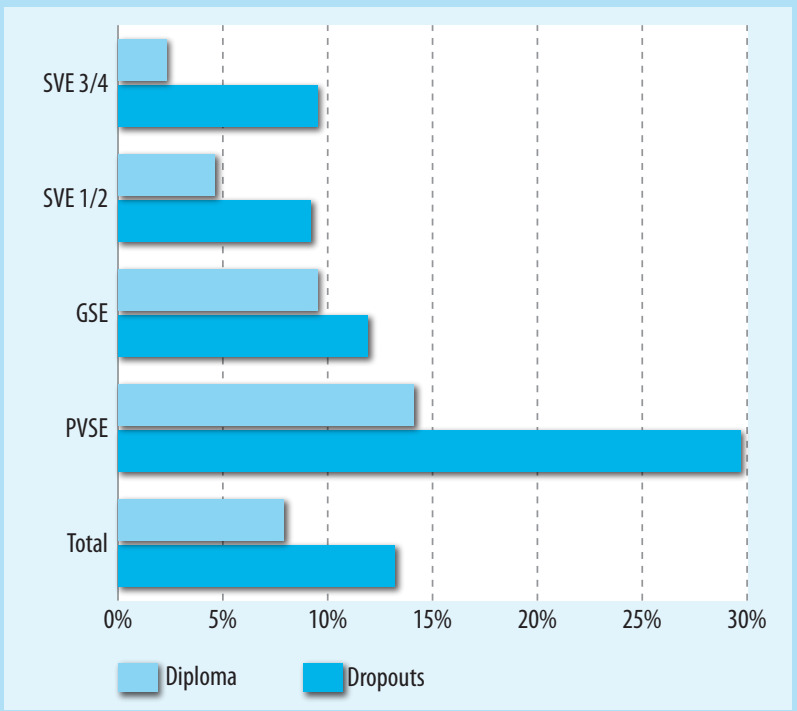

Figure 3 shows that all in all, dropouts indicated slightly more often that they had been bullied than qualified schoolleavers ( $3 \%$ against $8 \%$ ). This applies to dropouts and qualified school-leavers at all education levels. In particular in PVSE, the differences between qualified school-leavers and dropouts are large: $30 \%$ of all PVSE dropouts said that they had been bullied, against I $4 \%$ of the qualified PVSE school-leavers. In the group of 'qualified school-leavers at SVE Levels 3/4', hardly anyone had been bullied (2\%).

When pupils (whether dropout or qualified schoolleaver) were bullied, this was generally because of their appearance $(5 \%$ of the dropouts, $4 \%$ of the qualified school-leavers) or because of an illness or disability (3\% of the dropouts, I\% of the qualified school-leavers). Religion or sexual inclination was hardly ever reported as a reason for bullying (0.7\% of the dropouts, $0.4 \%$ of the qualified school-leavers). Compared with qualified PVSE school-leavers, PVSE dropouts were bullied more often in particular because of their appearance (I2\% against $7 \%$ ) and their illness or disability (9\% against I\%).

\section{Current occupation}

After approximately eighteen months the majority of all dropouts indicate that their main activity was work (37.5\%) or that they had gone back to school (35.4\%) (see Table 5). This can be deduced from the answers given to the question 'What are you doing at the moment' in the questionnaire. Although, strictly speaking, this does not mean that $37.5 \%$ 
belongs to the working population, the answers to this question give a good indication of the main occupation of the respondents. Just like the qualified school-leavers, most dropouts from SGSE/PUE and PVSE return to the education system; approximately $70 \%$ of them was doing a course at the time of the survey. SVE dropouts were clearly more active on the labour market. Even though they did not have a basic qualification either, some $49 \%$ of the schoolleavers at Levels I/2 and almost $47 \%$ of those at Levels 3/4 indicated that they had a job at the time of the survey. Another striking fact is that among dropouts at SVE Levels $\mathrm{I} / 2$, a relatively large group of youngsters indicated that they were neither working nor doing a course.

That there is a relationship between the reasons for dropping out and the personal situation of respondents at the time of the survey, appears from Table 6. The dropouts who stopped their studies because of health complaints, personal problems or care duties, were the most likely ones to indicate that they were neither working nor studying at the time of the survey. Most of the youngsters who had dropped out because they preferred the labour market, had a job. However, the table also shows that not all who had chosen the wrong course in terms of type or level, had chosen a more appropriate course and re-entered the education system. Many of these indicated that their occupation at the time of the survey was 'work'.

Of the entire group of dropouts, just under $40 \%$ were presenting themselves on the labour market. On average, one in five is unemployed; among PVSE dropouts on the labour market, the figure is as high as approximately $36 \%$. The quality of the jobs found was also far from perfect. Table 7 shows a number of major labour market indicators for both dropouts and qualified school-leavers who did obtain a basic qualification at SVE Level 2. Across the entire group of dropouts, more than half had a temporary job, and almost $55 \%$ was satisfied to very satisfied with the job. Among the qualified school-leavers, the percentage of those who had a temporary job was considerably lower, and $65 \%$ indicated that they were satisfied to very satisfied with their current jobs. Dropouts were slightly more often in paid employment than school-leavers who did have a basic qualification. The large difference between entering the labour market with or without a basic qualification is reflected in particular in the wages: qualified school-leavers at SVE Level 2 earn considerably more than dropouts

Table 5

What are they doing at the moment of survey? (\%)

\begin{tabular}{|c|c|c|c|c|c|}
\hline & GSE & PVSE & SVE $1 / 2$ & SVE $3 / 4$ & Tota \\
\hline Work & 12 & 9 & 49 & 47 & 38 \\
\hline Study & 70 & 73 & 15 & 27 & 35 \\
\hline Combination of working \& learning & 6 & 4 & 4 & 7 & 5 \\
\hline Other & 12 & 15 & 32 & 19 & 22 \\
\hline Total & $100 \%$ & $100 \%$ & $100 \%$ & $100 \%$ & $100 \%$ \\
\hline
\end{tabular}

Table 6

What are they doing at the moment of survey, by most important reason for dropping out (\%)

\begin{tabular}{|c|c|c|c|c|c|c|c|c|c|}
\hline & $\begin{array}{r}\text { School- } \\
\text { related } \\
\text { causes }\end{array}$ & $\begin{array}{r}\text { Mental and } \\
\text { physical health } \\
\text { complaints }\end{array}$ & $\begin{array}{l}\text { Personal } \\
\text { problems }\end{array}$ & $\begin{array}{l}\text { Wrong } \\
\text { course }\end{array}$ & $\begin{array}{r}\text { Course } \\
\text { too hard }\end{array}$ & Labour market & Care duties & Moved & Other \\
\hline Work & 43 & 22 & 28 & 34 & 43 & 68 & 33 & 14 & 37 \\
\hline Study & 37 & 36 & 34 & 47 & 38 & 11 & 20 & 66 & 39 \\
\hline $\begin{array}{l}\text { Combination of } \\
\text { working \& learning }\end{array}$ & 5 & 5 & 3 & 8 & 5 & 5 & 0 & 0 & 4 \\
\hline Other, nl. & 15 & 37 & 35 & 11 & 15 & 16 & 47 & 20 & 21 \\
\hline Total & $100 \%$ & $100 \%$ & $100 \%$ & $100 \%$ & $100 \%$ & $100 \%$ & $100 \%$ & $100 \%$ & $100 \%$ \\
\hline
\end{tabular}

Table 7

Labour market indicators

\begin{tabular}{|c|c|c|c|c|c|c|}
\hline & \multicolumn{5}{|c|}{ Dropouts } & \multirow{3}{*}{$\begin{array}{r}\text { SVE } 2 \\
\text { qualified } \\
\%\end{array}$} \\
\hline & GSE & PVSE & SVE $1 / 2$ & SVE $3 / 4$ & Total & \\
\hline & $\%$ & $\%$ & $\%$ & $\%$ & $\%$ & \\
\hline Unemployment & 25 & 36 & 26 & 13 & 20 & 8 \\
\hline Temporary appointment & 41 & 64 & 60 & 54 & 56 & 38 \\
\hline Paid job & 85 & 56 & 74 & 76 & 75 & 64 \\
\hline \multirow[t]{2}{*}{ (Very) satisfied with job } & 63 & 62 & 55 & 54 & 55 & 65 \\
\hline & $€$ & $€$ & $€$ & $€$ & $€$ & $€$ \\
\hline Hourly wages & 7,48 & 5,25 & 7,41 & 7,31 & 7,26 & 9,78 \\
\hline Monthly wages & 872 & 657 & 1.072 & 969 & 991 & 1.412 \\
\hline
\end{tabular}


without a basic qualification. The former have hourly wages of $€ 9.78$, whereas the latter earn only $€ 7.26$ per hour.

Figure 4 shows that a large part of the jobs consists of unskilled work, that is, jobs that do not require any diploma. This is the case in particular among PVSE dropouts. As can be seen in Table 7 , GSEs dropouts do best in relative terms, also where the required level for the job found is concerned.

Figure 4

Required education level for current job

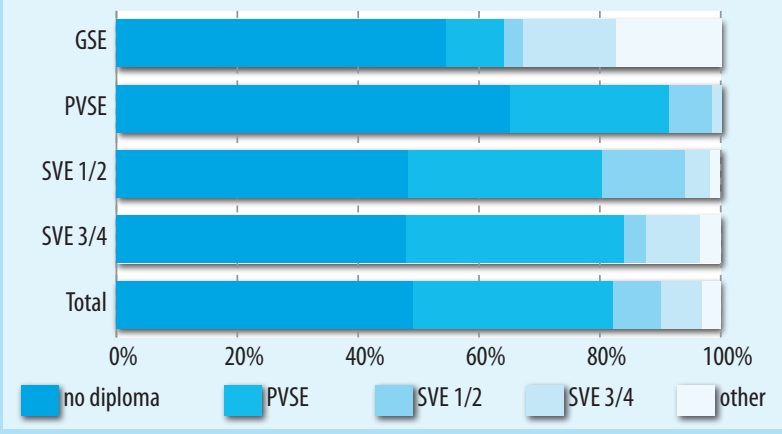

Figure 5

Percentage of dropouts neither involved in the labour market nor studying, by main reason for dropping out

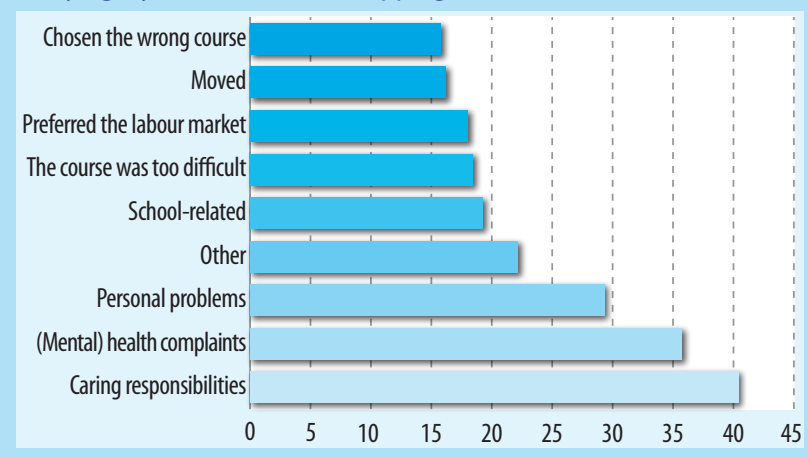

That there are differences in the success on the labour market between dropouts and qualified school-leavers, is to be expected. Table 8 also shows that the inactive group is relatively much larger among the dropouts than among the qualified school-leavers. Of all dropouts, some $64 \%$ have a job or are doing a course, almost $8 \%$ are looking for a job and almost $28 \%$ have no job, are not doing a course and are not looking for a job either. Among the comparable qualified school-leavers, this percentage is less than $9 \%$. Looking at the reason for dropping out (see Table 8), it appears that in particular among those who left school because of health or personal problems, and among those who dropped out because of care duties, many are neither involved in the labour market nor studying. Pupils who had stopped because they had initially chosen the wrong course, as expected, usually returned to the education system.

\section{Plans for the future and regrets}

An important question is to what extent dropouts have permanently left the education system. Table 9 shows what plans for the future respondents had with respect to their educational careers. The table indicates that there is a considerable difference between dropouts from GSE and PVSE on the one hand, and SVE dropouts on the other. Only a small part of the GSE (5.2\%) and the PVSE (9.8\%) dropouts had no intention of returning to the education system in the future. Among the SVE dropouts, this group is considerably larger. A smaller part of the latter group also indicated that they were doing a course or had already registered for a new course. This will be due partly to the fact that former SVE pupils, in spite of the lack of basic qualification, are more labour market-oriented than GSE and PVSE dropouts.

As the table shows, doubts about which course to choose is an important reason why part of the respondents had not started a new course yet. Expenses also play a major role; for almost one quarter of the respondents who were neither doing a new course nor had registered for one, the costs involved in embarking on a new course had stopped them from doing so. Another common reason is 'personal circumstances'. Looking at the factors that might contribute to the decision to do another course, it turns out that these are manifold. A contribution towards the study costs is one of these factors; another important factor is the possibility of combining studying and work. More support, both in the process of choosing a course and during the course itself, may also contribute to higher education participation rates among dropouts.

Figure 6 shows to what extent dropouts later regretted their decision to leave school. Strikingly, only a small part of the dropouts - I2.6\% for the group as a whole - indicated that they regretted their decision in the sense that they would not make the same decision again. This group is relatively the largest among SVE Levels I/2 dropouts. Approximately 35\% indicated that, although they had regrets, circumstances had left them no other choice at the time, implying that they would (have to) take the same decision again. Compared to the last survey, a shift has taken place. The group who had regrets but could not have done anything else, has increased by some $8 \%$ points, while each of the other two groups decreased by some $4 \%$ points. This means that the group who had real regrets may have shrunk, but the group who had no regrets at all has also decreased and relatively more youngsters were 'forced' to stop. 
Figure 6

Regrets about leaving school, by education level

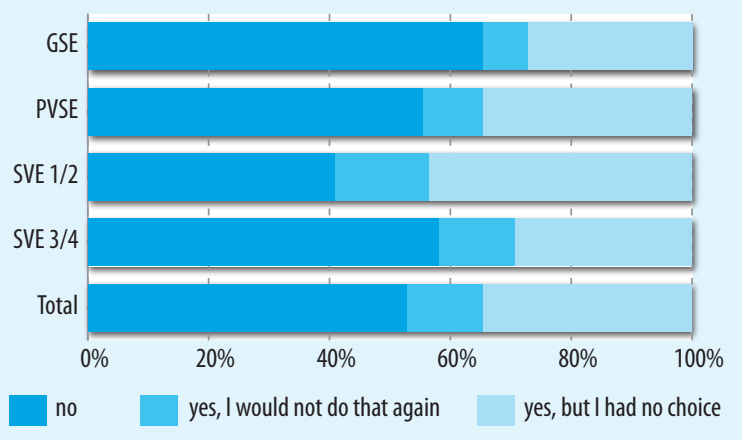

To what extent dropouts later regret their decision to drop out of the course they were taking, depends largely on the reason why they stopped. They have the least regrets if the main reason was that they had chosen the wrong course (see Table Io). Similarly, the main reason for dropping out is also often the explanation for the high percentage of respondents who stopped their courses more or less involuntarily. A little more than $40 \%$ of the dropouts who had stopped because of care duties, indicated that they regretted this, but that they had had no other choice; among those who stopped because of health complaints, this is also a large group (almost 36\%).

These figures may also provide an explanation for the relative increase of the group who stopped involuntarily, compared to the previous year. Health complaints and care duties are reasons that government institutions and schools cannot easily influence. If schools, by providing better support when pupils choose a course and better coaching, were able to have a positive influence on the number of dropouts, the group of those who leave school because of health complaints or care duties, will grow in relative terms, in spite of possibly increasingly efficient policies.

Table 8

Proportion of school-leavers that is neither active on the labour market nor studying, by last education level (\%)

\begin{tabular}{|c|c|c|c|c|c|}
\hline & \multicolumn{4}{|c|}{ Dropouts } & \multirow{2}{*}{$\begin{array}{r}\text { Qualified school-leavers } \\
\text { not available on } \\
\text { the labour market nor } \\
\text { studying }\end{array}$} \\
\hline & $\begin{array}{r}\text { Working or } \\
\text { studying }\end{array}$ & Looking for work' & $\begin{array}{r}\text { Not available on the } \\
\text { labour market } \\
\text { nor studying }\end{array}$ & Total & \\
\hline GSE & 76 & 3 & 21 & $100 \%$ & 7 \\
\hline PVSE & 72 & 5 & 24 & $100 \%$ & 6 \\
\hline SVE $1 / 2$ & 53 & 14 & 33 & $100 \%$ & 12 \\
\hline SVE $3 / 4$ & 66 & 6 & 28 & $100 \%$ & 9 \\
\hline Total & 64 & 8 & 28 & $100 \%$ & 8 \\
\hline
\end{tabular}

' Unlike the unemployment rate, this percentage is based on the full group of dropouts, not just the group that is available on the labour market, and hence it is not equal to the unemployment rate.

Table 9

Study plans for the future (\%)

\begin{tabular}{|c|c|c|c|c|c|}
\hline & $\begin{array}{l}\text { Is registered } \\
\text { with a school }\end{array}$ & $\begin{array}{l}\text { Intends to but does } \\
\text { not know yet which } \\
\text { course and when }\end{array}$ & $\begin{array}{l}\text { Is doing } \\
\text { a course }\end{array}$ & $\begin{array}{r}\text { No intention } \\
\text { to study }\end{array}$ & Total \\
\hline GSE & 20 & 34 & 42 & 5 & $100 \%$ \\
\hline PVSE & 13 & 41 & 37 & 10 & $100 \%$ \\
\hline SVE $1 / 2$ & 11 & 54 & 14 & 22 & $100 \%$ \\
\hline SVE $3 / 4$ & 8 & 48 & 28 & 16 & $100 \%$ \\
\hline Total & 11 & 47 & 26 & 16 & $100 \%$ \\
\hline
\end{tabular}

Table 10

Regrets the choice to leave school, by main reason for dropping out (\%)

\begin{tabular}{|l|r|r|r|r|} 
& No & Yes, I would not do that again & Yes, but l had no choice & Total \\
\hline School-related & 75 & 6 & 19 & 100 \\
\hline Physical or mental health complaints & 53 & 11 & 36 & 100 \\
\hline Personal problems & 57 & 14 & 29 & 100 \\
\hline Chosen the wrong course & 79 & 5 & 16 & 18 \\
\hline Course too hard & 76 & 6 & 18 & 100 \\
\hline Preferred the labour market & 74 & 8 & 40 & 100 \\
\hline Care duties & 44 & 16 & 16 & 100 \\
\hline Moved & 74 & 10 & 22 & 100 \\
\hline Other & 70 & 8 & 10 & 100 \\
\hline
\end{tabular}




\section{Conclusions}

This fact sheet summarizes the reasons for dropping out, the situation at school, current occupation and plans for the future of unqualified dropouts. The main findings include:

- School-related physical or mental health complaints constitute the main reasons for dropping out;

- In particular among pupils who skip school because of personal problems, truancy may be an early signal for dropping out;

- Dropouts indicate slightly more often than qualified school-leavers that they were bullied at school;

- Some $13 \%$ of all dropouts indicate that they regret their decision to abandon the course they were doing. 


\section{Annexes}

Table B1

Respondents' background characteristics (\%)

\begin{tabular}{|c|c|c|c|c|c|}
\hline & GSE & PVSE & SVE Levels $1 / 2$ & SVE Levels $3 / 4$ & Total \\
\hline \multicolumn{6}{|l|}{ Gender } \\
\hline male & 49 & 60 & 52 & 40 & 49 \\
\hline female & 51 & 41 & 48 & 60 & 52 \\
\hline \multicolumn{6}{|l|}{ Ethnicity } \\
\hline Western immigrant & 12 & 8 & 6 & 8 & 8 \\
\hline Non-Western immigrant & 10 & 18 & 20 & 14 & 16 \\
\hline Indigenous & 78 & 74 & 73 & 78 & 76 \\
\hline \multicolumn{6}{|l|}{ Family situation } \\
\hline Two-parent family & 64 & 54 & 44 & 48 & 49 \\
\hline Single-parent family & 21 & 30 & 26 & 21 & 24 \\
\hline I live on my own & 9 & 3 & 14 & 21 & 14 \\
\hline Other, namely & 5 & 14 & 16 & 11 & 13 \\
\hline \multicolumn{6}{|l|}{ Language spoken by parents } \\
\hline (almost) always Dutch & 78 & 70 & 62 & 71 & 69 \\
\hline Dutch and another language & 9 & 13 & 13 & 12 & 12 \\
\hline (almost) always another language & 2 & 4 & 5 & 2 & 3 \\
\hline Not applicable & 11 & 13 & 20 & 14 & 16 \\
\hline \multicolumn{6}{|l|}{ Parents' education level } \\
\hline \multicolumn{6}{|l|}{ Father } \\
\hline Primary education & 5 & 7 & 12 & 10 & 9 \\
\hline Lower professional education & 12 & 27 & 35 & 33 & 30 \\
\hline Secondary education & 8 & 9 & 8 & 7 & 8 \\
\hline Secondary vocatinal education & 18 & 26 & 29 & 24 & 25 \\
\hline Higher education & 57 & 32 & 16 & 27 & 28 \\
\hline \multicolumn{6}{|l|}{ Moeder } \\
\hline Primary education & 2 & 8 & 13 & 10 & 10 \\
\hline Lower professional education & 16 & 24 & 32 & 38 & 31 \\
\hline Secondary education & 11 & 10 & 11 & 7 & 9 \\
\hline Secondary vocatinal education & 27 & 33 & 31 & 27 & 29 \\
\hline Higher education & 43 & 25 & 12 & 18 & 20 \\
\hline \multicolumn{6}{|l|}{ Children } \\
\hline Yes & 1 & 2 & 14 & 7 & 8 \\
\hline No & 99 & 98 & 86 & 94 & 93 \\
\hline
\end{tabular}


Table B2

Main reasons for leaving school prematurely, including classification by main categories* (\%)

\begin{tabular}{|c|c|c|c|c|c|c|}
\hline & & GSE & PVSE & $\begin{array}{r}\text { SVE Levels } \\
1 / 2\end{array}$ & $\begin{array}{r}\text { SVE Levels } \\
3 / 4\end{array}$ & Total \\
\hline \multirow[t]{13}{*}{ School-related causes } & problems during traineeship/work placement (e.g. dismissal) & 1 & 0 & 9 & 5 & 5 \\
\hline & I had problems with teachers/school management & 6 & 8 & 5 & 3 & 5 \\
\hline & I had problems with other pupils & 0 & 3 & 0 & 1 & 1 \\
\hline & I did not feel save at school & 1 & 4 & 0 & 0 & 1 \\
\hline & the course was badly organised & 8 & 4 & 6 & 10 & 7 \\
\hline & (I received insufficient support) & 2 & 1 & 1 & 0 & 1 \\
\hline & (quality of teaching was bad) & 0 & 0 & 0 & 0 & 0 \\
\hline & (I was bullied) & 0 & 1 & 0 & 0 & 0 \\
\hline & I wanted to shift courses & 7 & 7 & 5 & 4 & 5 \\
\hline & the content of the course was not what I wanted (after all) & 2 & 2 & 10 & 18 & 11 \\
\hline & I thougt the level of the course was too low & 0 & 3 & 2 & 4 & 3 \\
\hline & (indication special education) & 1 & 2 & 0 & 0 & 0 \\
\hline & the course was too difficult and/or I failed the finale examination & 17 & 7 & 6 & 3 & 6 \\
\hline Subtotal & & 45 & 40 & 44 & 48 & 45 \\
\hline \multirow[t]{4}{*}{ Physical or mental health complaints } & illness & 9 & 6 & 6 & 7 & 7 \\
\hline & addiction problems & 2 & 2 & 4 & 1 & 2 \\
\hline & mental problems & 13 & 19 & 5 & 8 & 9 \\
\hline & (disability) & 0 & 0 & 1 & 0 & 0 \\
\hline Subtotal & & 24 & 27 & 15 & 16 & 18 \\
\hline \multirow[t]{5}{*}{ Personal problems } & relational problems/family problems (e.g. parents' divorce) & 5 & 8 & 6 & 4 & 5 \\
\hline & contact with the police/law & 0 & 1 & 2 & 1 & 1 \\
\hline & (financial reasons) & 0 & 0 & 0 & 1 & 1 \\
\hline & pregnancy & 0 & 1 & 4 & 4 & 3 \\
\hline & combining school and caring for children and/or family, was too much & 0 & 1 & 1 & 0 & 1 \\
\hline Subtotal & & 5 & 11 & 13 & 10 & 10 \\
\hline \multirow[t]{2}{*}{ Labour market } & I preferred to work & 3 & 3 & 12 & 10 & 9 \\
\hline & I needed an income, so I started working & 2 & 1 & 6 & 4 & 4 \\
\hline Subtotal & & 5 & 4 & 18 & 14 & 13 \\
\hline \multirow[t]{3}{*}{ Other } & I moved house & 10 & 5 & 1 & 1 & 3 \\
\hline & other & 11 & 11 & 8 & 11 & 10 \\
\hline & (school forced me to stop) & 1 & 2 & 1 & 0 & 1 \\
\hline Subtotal & & 21 & 18 & 9 & 12 & 13 \\
\hline Total & & 100 & 100 & 100 & 100 & 100 \\
\hline
\end{tabular}

* A number of respondents chose 'another main reason, namely' as main reason for leaving school prematurely. The answers given by these respondents were classified in existing or new categories as much as possible. These new categories were marked in the table by means of brackets '(...)'. 
Table B3

Reasons for truancy, including classification by main categories* (\%)

\begin{tabular}{|c|c|c|c|c|c|c|}
\hline & & GSE & PVSE & SVE Levels $1 / 2$ & SVE Levels 3/4 & Total \\
\hline \multirow[t]{10}{*}{ School-related causes } & (Bullying) & 0 & 3 & 0 & 2 & 1 \\
\hline & (School, other) & 6 & 4 & 2 & 3 & 3 \\
\hline & (I was scared) & 0 & 2 & 0 & 0 & 0 \\
\hline & (Problems in class) & 0 & 1 & 1 & 2 & 1 \\
\hline & (Lessons, cancelled) & 0 & 2 & 1 & 3 & 2 \\
\hline & (Problems with teachers) & 2 & 3 & 1 & 1 & 1 \\
\hline & Some lessons were uninteresting & 25 & 10 & 18 & 27 & 22 \\
\hline & Entire course uninteresting & 8 & 7 & 17 & 19 & 16 \\
\hline & (Lessons too easy) & 1 & 1 & 2 & 1 & 1 \\
\hline & (Lessons too difficult) & 0 & 0 & 1 & 1 & 1 \\
\hline Subtotal & & 42 & 32 & 43 & 58 & 49 \\
\hline \multirow[t]{4}{*}{ Physical or mental health complaints } & Too tired & 15 & 16 & 11 & 12 & 12 \\
\hline & (Illness) & 1 & 1 & 1 & 2 & 2 \\
\hline & (Mental problems) & 5 & 7 & 2 & 3 & 3 \\
\hline & (Addiction) & 1 & 0 & 2 & 0 & 1 \\
\hline Subtotal & & 22 & 24 & 16 & 17 & 18 \\
\hline \multirow[t]{3}{*}{ Personal problems } & (Home environment) & 5 & 4 & 3 & 2 & 3 \\
\hline & (Private) & 0 & 1 & 2 & 2 & 1 \\
\hline & (Pregnant) & 0 & 0 & 1 & 0 & 1 \\
\hline Subtotal & & 5 & 6 & 5 & 3 & 4 \\
\hline Labour market & Preferred to work and earn money & 2 & 5 & 13 & 6 & 8 \\
\hline Subtotal & & 2 & 5 & 13 & 6 & 8 \\
\hline \multirow[t]{4}{*}{ Other } & Preferred to spend time with friends & 16 & 21 & 12 & 7 & 11 \\
\hline & Preferred to do sports & 3 & 1 & 0 & 1 & 1 \\
\hline & Other & 10 & 11 & 9 & 7 & 9 \\
\hline & (Multiple reasons) & 2 & 1 & 1 & 1 & 1 \\
\hline Subtotal & & 31 & 34 & 22 & 16 & 22 \\
\hline Total & & 100 & 100 & 100 & 100 & 100 \\
\hline
\end{tabular}

* A number of respondents chose 'other, namely' as main reason for skipping school. The answers given by these respondents were classified in existing or new categories as much as possible. These new categories were marked in the table by means of brackets '(...)'. 


\section{Imprint}

(C) Research Centre for Education and the Labour Market (ROA). Nothing in this publication may be duplicated in any way without prior written permission from ROA's director.

Research Centre for Education and the Labour Market Maastricht University

School of Business and Economics secretary-roa-sbe@maastrichtuniversity.nl www.roa.nl

\section{Layout}

ROA Secretariat, Maastricht

August 2012 
Researchcentre for Education and the Labour Market

P.O. Box 616

6200 MD Maastricht

The Netherlands

$\mathrm{T}+31433883647$

$\mathrm{F}+31433884914$

secretary-roa-sbe@maastrichtuniversity.n

www.roa.nl

Maastricht University

School of Business and Economics 